\title{
HIGH DISTRIBUTION OF 16S rRNA METHYLASE GENES $r m t B$ AND armA AMONG ENTEROBACTER CLOACAE STRAINS ISOLATED FROM AN AHVAZ TEACHING HOSPITAL, IRAN
}

\author{
MANSOUR AMIN ${ }^{1,2}$, GOLSHAN MEHDIPOUR ${ }^{2}$ and TAHEREH NAVIDIFAR ${ }^{2 *}$ \\ ${ }^{1}$ Infectious and Tropical Diseases Research Center, Health Research Institute, \\ Ahvaz Jundishapur University of Medical Sciences, Ahvaz, Iran \\ ${ }^{2}$ Department of Microbiology, School of Medicine, Ahvaz Jundishapur \\ University of Medical Sciences, Ahvaz, Iran
}

(Received: 5 December 2018; accepted: 4 January 2019)

\begin{abstract}
The emergence of 16S rRNA methylase genes encoded on plasmids confers high-level aminoglycoside resistance (HLAR). This study aimed to investigate the prevalence of 16S rRNA methylases among Enterobacter cloacae strains isolated from an Ahvaz teaching hospital, Iran. A total of 68 E. cloacae clinical strains were collected between November 2017 and September 2018. The MICs of aminoglycosides were assessed using the agar dilution method. The presence of 16S rRNA methylase genes, including armA, rmtA to $r m t H$, and $n m p A$ was evaluated by PCR. The transferability of $16 \mathrm{~S}$ rRNA methylase-harboring plasmids was evaluated by conjugation assay. The genetic diversity of all isolates was evaluated by ERIC-PCR. The arm $A$ and $r m t B$ genes were the only $16 \mathrm{~S}$ rRNA methylase genes detected in this study ( 29 out of 68 isolates; $42.64 \%$ ). The transferability by conjugation was observed in $23 \mathrm{rmtB}$ or/and armA positive donors. HLAR phenotype was in 33 of 68 strains. Ten clonal types were obtained by ERIC-PCR and significant associations $(p<0.05)$ were between the clone types and aminoglycoside susceptibility, as well as with profile of the 16S rRNA methylase genes. In conclusion, both horizontal transfer and clonal spread are responsible for dissemination of the $r m t B$ and $\operatorname{arm} A$ genes among E. cloacae strains.
\end{abstract}

Keywords: 16S rRNA methylase, Enterobacter cloacae, ERIC-PCR

\section{Introduction}

Enterobacter spp. as important opportunistic pathogens have usually emerged in nosocomial infections. The extensive use of antibiotics in the hospital

*Corresponding author; E-mail: roya_67@ymail.com 
settings has increased the emergence of multidrug-resistant Enterobacter spp. isolates in hospitals. The most frequent human infections caused by Enterobacter spp. are bacteremia, endocarditis, septic arthritis, osteomyelitis, lower respiratory tract, urinary tract, and intra-abdominal infections [1].

Aminoglycosides are considered as a group of broad-spectrum antibiotics that have been used empirically for the treatment of life-threatening Gramnegative infections. They can inhibit the protein synthesis of bacteria by binding to the 16S rRNA. However, the widespread use of aminoglycosides has caused some selective pressures for the emergence of resistant organisms [2].

Resistance to aminoglycoside agents occurs primarily through three different mechanisms: (a) the modification of the $16 \mathrm{~S}$ rRNA and ribosomal protein targets, (b) the reduction of uptake and increment of efflux, and (c) aminoglycosidemodifying enzymes (AMEs). Among them, only aminoglycoside phosphotransferases can produce a high level of resistance [3].

The high-level aminoglycoside resistance (HLAR) is established by $16 \mathrm{~S}$ rRNA methylases, which are usually encoded on plasmids. Moreover, these genes can be simply transferred among Gram-negative bacilli populations especially in hospital setting through the horizontal gene-transfer mechanisms [4]. In contrast to AMEs that have a range of substrates, 16S rRNA methylases confer HLAR phenotype to almost all common aminoglycosides, such as amikacin, kanamycin, tobramycin, and gentamicin [5].

In 2002, the first $16 \mathrm{~S}$ rRNA methylase gene, later known as armA, was identified as the part of a plasmid sequence of a clinical isolate of Citrobacter freundii in Poland [5]. Since then, ten 16S rRNA methylase plasmid-mediated genes, $r m t A$ to $r m t H$, $\operatorname{armA}$, and $n m p A$, have been identified in clinical or veterinary bacterial isolates [6-8]. Previous studies in European and East Asia countries indicated a relativity high prevalence of $\operatorname{arm} A, \mathrm{rmt} B$ or both genes in the Enterobacteriaceae family [9-13]. In this article, we first investigated the prevalence of $16 \mathrm{~S}$ rRNA methylases in Enterobacter cloacae strains isolated from various clinical samples in Ahvaz, Iran. The molecular typing of these isolates was performed using enterobacterial repetitive intergenic consensus-polymerase chain reaction (ERIC-PCR) method.

\section{Materials and Methods}

A total of 86 non-duplicate clinical E. cloacae isolates were collected between November 2017 and September 2018 from clinical samples of hospitalized patients in ICU of the Golestan teaching Hospital in Ahvaz, Iran. All $E$. cloacae isolates from the different clinical samples were obtained from the 
hospital laboratory. The study design was approved by the Research Ethics Committee of Ahvaz Jundishapur University of Medical Sciences, Iran (IR.AJUMS.REC.1396.409). All strains were identified by colony morphology, biochemical tests, and sequencing 16S rRNA gene [14].

\section{Determination of antimicrobial susceptibility of aminoglycosides}

The minimum inhibitory concentrations (MICs) of aminoglycoside agents, including amikacin, kanamycin, and gentamycin, were assessed using agar dilution method and their results were interpreted according to CLSI guidelines [15]. The presence of HLAR phenotype is defined as MICs $\geq 256 \mu \mathrm{g} / \mathrm{ml}$ of gentamicin, amikacin, or kanamycin.

\section{DNA extraction}

The whole genome was extracted using boiling method as described previously [16]. In addition, the extraction of plasmid DNA was performed using a Plasmid Purification Kit (CinnaGene, Iran) according to manufacturer's procedure.

\section{ERIC-PCR typing and analysis}

The genetic diversity of E. cloaceae isolates was evaluated using the ERIC-PCR [17]. The primer sequences used were ERIC-F (5'-ATGTAA GCTCCTGGGGATTCAC-3') and ERIC-R (5'-AAGTAAGTGACTGGGGTGA GCG-3'). The PCR reaction was performed in the final volume of $20 \mu \mathrm{l}$. The amplification mixture consisted of $1 \mathrm{U}$ Taq DNA polymerase, $1.5 \mathrm{mM} \mathrm{MgCl}$, $200 \mu \mathrm{M}$ dNTPs, $0.25 \mu \mathrm{M}$ of each primer, $10 \times$ PCR buffer, $5 \mu 1$ of template DNA, and distilled water up to a final volume of $20 \mu$. The amplification process was performed in Mastercycler Nexus Thermal Cycler Gradient (Eppendorf, Hamburg, Germany) with one cycle of initial denaturation at $94{ }^{\circ} \mathrm{C}$ for $5 \mathrm{~min}$, followed by 35 cycles of denaturation at $94^{\circ} \mathrm{C}$ for $60 \mathrm{~s}$, annealing at $55^{\circ} \mathrm{C}$ for $60 \mathrm{~s}$, extension at $72{ }^{\circ} \mathrm{C}$ for $90 \mathrm{~s}$, with a cycle of final extension at $72{ }^{\circ} \mathrm{C}$ for $10 \mathrm{~min}$. The amplified products were resolved on agarose gel $1.5 \%$, stained with $0.5 \mu \mathrm{g} / \mathrm{ml}$ ethidium bromide. The data analysis was performed using the Gel Compare II software version 6.6 (Applied Maths, Sint-Martens-Latem, Belgium). The similarity pattern was calculated using the Unweighted-Pair Group Method (UPGMA)/the Dice similarity coefficient with a position tolerance of $1.5 \%$. Isolates with more than $80 \%$ similarity were considered an as clonal type. 
Molecular identification of $16 S$ rRNA methylases

The amplification of genes encoding 16S rRNA methylases, including $r m t A$ to $r m t H, \operatorname{arm} A$, and $n m p A$ on both DNA extracted from plasmid and whole genome was performed by PCR, as described previously [13]. The primer sequences used for these genes are presented in Table I. The single PCR reactions were established in the final volume of $20 \mu \mathrm{l}$. The amplification mixture consisted of $1 \mathrm{U}$ Taq DNA polymerase, $1.5 \mathrm{mM} \mathrm{MgCl}_{2}, 200 \mu \mathrm{M}$ dNTPs, $0.35 \mu \mathrm{M}$ of each primer, $10 \times$ PCR buffer, $3 \mu \mathrm{l}$ of template DNA, and distilled water up to a final volume of $20 \mu \mathrm{l}$. The amplification conditions were as follows: one cycle of initial denaturation at $94{ }^{\circ} \mathrm{C}$ for $3 \mathrm{~min}$, followed by 35 cycles of denaturation at $94{ }^{\circ} \mathrm{C}$ for $60 \mathrm{~s}$, annealing temperatures (mentioned in Table I) for $30 \mathrm{~s}$, extension at $72{ }^{\circ} \mathrm{C}$ for $30 \mathrm{~s}$, with a cycle of final extension at $72{ }^{\circ} \mathrm{C}$ for $10 \mathrm{~min}$. The PCR products were visualized on a $1 \%$ agarose gel stained with safe stain. DNA sequencing of PCR products of four randomly selected isolates was recommended for both the DNA strands (Bioneer, South Korea).

\section{Conjugation experiment}

The ability of the 16S rRNA methylase gene-positive isolates for the plasmid transfer into $E$. coli J53 Azide $^{\circledR}$ as the recipient was evaluated using

Table I. Primer used for the amplification of the 16S rRNA methylase genes

\begin{tabular}{|c|c|c|c|}
\hline Gene & Primer sequence $\left(5^{\prime}-3^{\prime}\right)$ & $\mathrm{bp}$ & $\begin{array}{c}\text { Annealing } \\
\text { temperature }\left({ }^{\circ} \mathrm{C}\right)\end{array}$ \\
\hline \multirow[t]{2}{*}{$\operatorname{arm} A$} & F - AAAGTACAATCAGGGGCAGTT & 269 & 54 \\
\hline & R - TCGTCGTCTTTAACTTCCCAA & & \\
\hline \multirow[t]{2}{*}{$r m t A$} & F - CTAGCGTCCATCCTTTCCTC & 634 & 55 \\
\hline & R - TTGCTTCCATGCCCTTGCC & & \\
\hline \multirow[t]{2}{*}{$r m t B$} & F - GCTTTCTGCGGGCGATGTAA & 173 & 54 \\
\hline & R - ATGCAATGCCGCGCTCGTAT & & \\
\hline \multirow[t]{2}{*}{$\mathrm{rmtC}$} & F - CGAAGAAGTAACAGCCAAAG & 711 & 60 \\
\hline & $\mathrm{R}$ - A TCCСААСАТСТСТСССАСТ & & \\
\hline \multirow[t]{2}{*}{$r m t D$} & F - CGGCACGCGATTGGGAAGC & 401 & 62 \\
\hline & R - CGGAAACGATGCGACGAT & & \\
\hline \multirow[t]{2}{*}{$r m t E$} & F - TGGTTGCAGAGGTTCTGTCGAGC & 518 & 57 \\
\hline & $\mathrm{R}$ - CGGCGTAACAGACACGGCATCA & & \\
\hline \multirow[t]{2}{*}{$r m t F$} & F - ATTCATCTGGGCTGCGTGCGAC & 338 & 54 \\
\hline & R - ACCAGCTCGTCCGACACCGTAA & & \\
\hline \multirow[t]{2}{*}{$r m t G$} & F - CGTGTATGCGCGTCTGTTGGGT & 420 & 56 \\
\hline & R - ACGGTGCGTTCGATTCGCCATT & & \\
\hline \multirow[t]{2}{*}{$r m t H$} & F - ACAAAAAGCCCAAGCAGGCGGT & 259 & 58 \\
\hline & R - CGGTGCAGCATCAGCGGGTTTA & & \\
\hline \multirow[t]{2}{*}{ птрA } & F - GGTCAGTTTGATCGTGTGCA & 195 & 59 \\
\hline & R - AGCTGCAATAACAAACACCACA & & \\
\hline
\end{tabular}


conjugation experiment [11]. The donor and recipient cells were mixed to each other in ratio 10:1 in lysogeny broth (LB) and incubated for an overnight at $37^{\circ} \mathrm{C}$. Transconjugants were selected on LB plates supplemented with sodium azide $(100 \mu \mathrm{g} / \mathrm{ml})$ and amikacin $(128 \mu \mathrm{g} / \mathrm{ml})$. The plasmid transfer of $16 \mathrm{~S}$ rRNA methylase genes into transconjugants was confirmed by the amplification of these genes using primers used in the previous section.

\section{Statistical analysis}

The descriptive statistics and $\chi^{2}$ tests were performed using SPSS version 16.0 (Chicago, IL, USA). Moreover, $\chi^{2}$ test was used for finding the association between the resistance to aminoglycosides in various clonal types and a $p$ value $<0.05$ was considered statistically significant.

\section{Results}

In this study, 68 E. cloacae isolates were collected from different clinical samples, including urine (47), wound (11), and blood (10). All isolates were confirmed as E. cloacae by standard biochemical tests and sequencing $16 \mathrm{~S}$ rRNA gene. The majority of these strains was resistant to gentamicin $(n=43 ; 63.23 \%)$, followed by amikacin $(n=38 ; 55.88 \%)$ and kanamycin $(n=35 ; 51.47 \%)$. Overall, the 16S rRNA methylase genes were identified in 29 (42.64\%) isolates. Moreover, $16(23.52 \%)$ strains harbored only armA, $7(10.29 \%)$ harbored only $r m t B$, and 6 (8.82\%) harbored both armA and $r m t B$ genes. According to the results obtained from sequencing, we observed that the arm $A$ and $r m t B$ genes had $100 \%$ identity with armA in K. pneumoniae BM4536, (GenBank AY220558) and rmtB in $K$. pneumonia NCCHD 1261-1 (GenBank LC424160.1). However, none of the strains harbored $r m t A, r m t C, r m t D, r m t E, r m t F, r m t G$, and $n m p A$ genes. All isolates harboring $16 \mathrm{~S}$ rRNA methylase genes were highly resistant to gentamicin, amikacin, and kanamycin (MICs $\geq 256 \mu \mathrm{g} / \mathrm{ml}$ ). The clinical samples of the 16S rRNA methylase gene-positive isolates were as follows: urine $(n=20)$, wound $(n=3)$, and blood $(n=6)$.

In this study, the HLAR phenotype was observed in 33 isolates. However, 4 out of these 33 isolates had neither armA nor $r m t B$ gene.

Conjugation experiments showed the horizontal transfer of the arm $A$ and $r m t B$ genes in 23 out of 29 strains. Susceptibility testing of these transconjugants to aminoglycosides approved the conjugation assay.

In this study, 68 E. cloacae strains were clustered into 10 clone types and 28 single type of ERIC-PCR. Figure 1 shows the dendrogram of ERIC-PCR of these isolates. In addition, Table II shows the distribution of MICs of amikacin, 

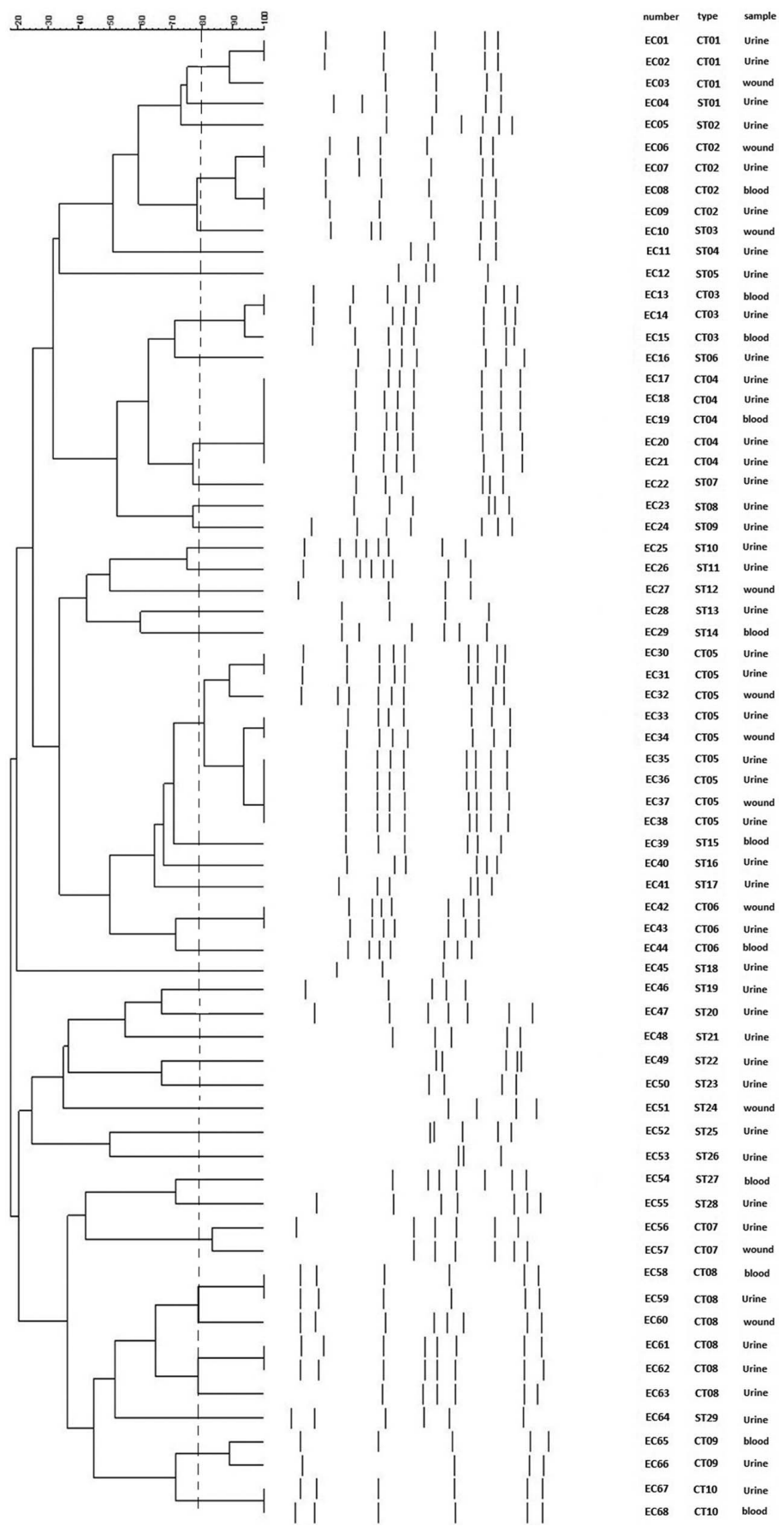

Figure 1. Dendrogram of 68 E. cloacae clinical strains based on ERIC-PCR profiles 


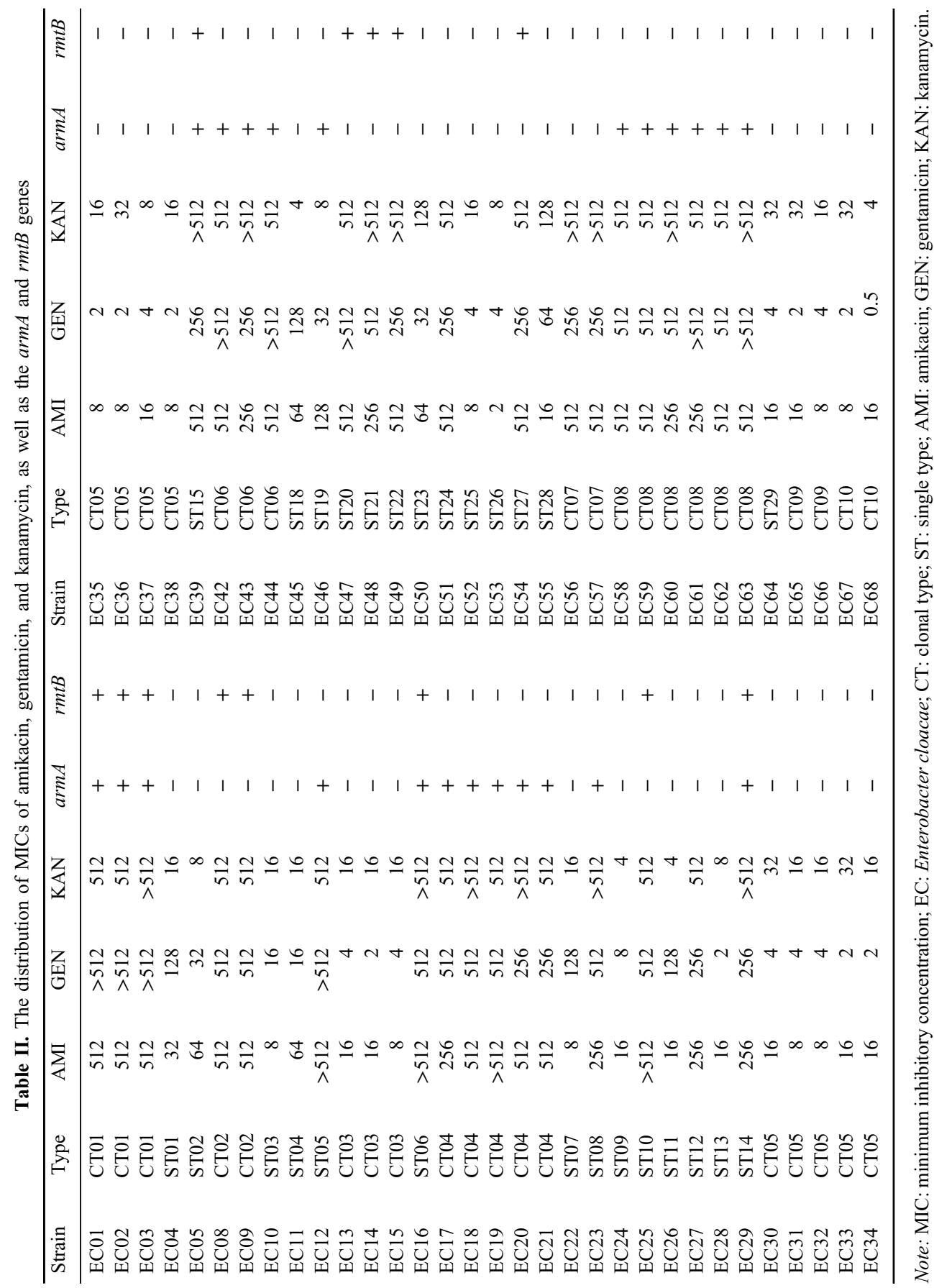


gentamicin, and kanamycin, as well as the $\operatorname{arm} A$ and $r m t B$ genes among 68 strains of $E$. cloacae based on ERIC-PCR patterns.

We found that all strains in a same clone type had similar 16S rRNA gene profile. There was a significant association $(p<0.05)$ between the clone types and antibiotic susceptibility to aminoglycoside agents, and the profile of $16 \mathrm{~S}$ rRNA genes (e.g., all armA- or $r m t B$-harboring isolates) was clonally related.

\section{Discussion}

The emergence of $16 \mathrm{~S}$ rRNA methylases genes among the Enterobactericeae family is raising serious concerns for the future of treatment with aminoglycosides. These genes are considered as one of the main determinants in the growing spread of HLAR phenotype [18]. Hence, the epidemiologic studies and analysis of the acquisition mechanisms of these determinants by clinical isolates are paramount for the prevention of their spread in healthcare settings.

In this study, the overall prevalence of the 16S rRNA methylase genes (armA and $r m t B$ ) among E. cloacae strains isolated from the various clinical samples was $42.64 \%$. The frequency rates of the $16 \mathrm{~S}$ rRNA methylase genes among Enterobacteriaceae family in other studies ranged from $0.66 \%$ to $46.34 \%$ $[11,18-22]$.

Our data indicated that the armA gene was more prevalent than the $r m t B$ gene in $E$. cloacae strains. This result is consistent with other reports indicating that arm $A$ had a higher prevalence relative to $r m t B$ among the Enterobacteriaceae family [11, 19-21]. Although the presence of $r m t A, r m t D$, and $r m t C$ genes has been confirmed by PCR among the Enterobacteriaceae family in India [22] and Saudi Arabia [12], these genes were not detected in this study and some other countries $[11,19,20,23]$. On the whole, the frequency rates of 16S rRNA methylase genes are highly dependent on the distribution pattern of plasmids harboring these genes.

As mentioned above, the 16S rRNA methylase genes are often encoded on self-transferable plasmids, which can be easily transferred to other species through the horizontal gene-transfer mechanisms, such as transconjugation and transformation. In this study, we confirmed the amplification of $16 \mathrm{~S}$ rRNA methylase genes on both DNA extracted from plasmid and whole genome for all strains harboring these genes. In addition, we showed that the aminoglycoside resistance was transferred to the recipient $E$. coli $\mathrm{J} 53$ by conjugation in 23 out of 29 isolates producing armA and/or $r m t B$ gene. This finding indicates that the 16S rRNA methylase genes are often located on self-transferable plasmids. However, the plasmid transfer in the six remaining strains failed via conjugation, which indicates 
that these plasmids were not transferable to the recipient E. coli J53. In consistence with our results, some previous studies also indicated that most strains producing 16S rRNA methylase had self-transferable plasmids by conjugation $[9,11,19]$. However, Yu et al. [18] found that most armA- or $r m t B$-positive donors transferred their plasmids into the recipient strains through transformation. This finding highlights two main mechanisms of the horizontal gene transfer in the dissemination of HLAR determinants.

In this study, we observed that 4 out of 33 strains with HLAR phenotype were lacking the $16 \mathrm{~S}$ rRNA methylase genes. Similar finding was also reported in a study conducted in China by Wang et al. [24] on Acinetobacter baumannii strains. Moreover, they showed that some strains with HLAR phenotype had genes encoding AMEs instead of the 16S rRNA methylase genes.

Molecular typing methods are considered as the important tools to identify the clonal relationship and the spread of nosocomial and geographical of an infectious agent. ERIC-PCR is a rapid and low-cost method that can differentiate the genetic variations of bacterial isolates. We showed that these 68 isolates were successfully differentiated into 10 clone types by ERIC-PCR. In addition, we indicated the clonal dissemination of armA and/or $r m t B$ gene-positive E. cloacae strains.

On the other hand, one of the serious concerns of the dissemination of $16 \mathrm{~S}$ rRNA methylase genes is the development of multidrug resistance through cotransfer of plasmids harboring these genes with other resistance determinants, including enzymes OXA types, MBLs, ESBLs, and PMQRs by the horizontal gene transfer. Moreover, the acquisition of resistance determinants to carbapenem and fluoroquinolones is a serious threat for the antibiotic therapy of infectious diseases caused by Gram-negative bacteria [25].

\section{Conclusions}

In this study, we showed the high distribution of $r m t B$ and $\operatorname{arm} A$ genes among E. cloacae strains. In addition, ERIC-PCR and conjugation indicated that both the horizontal gene transfer and clonal dissemination were responsible for the spread of the $r m t B$ and armA in E. cloacae strains. Hence, the regional epidemiologic studies for finding these genes in the clinical isolates are critical for the prevention from the dissemination of HLAR phenotype organisms.

\section{Acknowledgements}

This study is a part of MSc thesis of GM, which has been approved as a research (grant no. 96113) and was financially supported by Infectious and 
Tropical Diseases Research Center, Health Research Institute, Jundishapur University of Medical Sciences, Ahvaz, Iran. GM and TN carried out the laboratory tests. MA participated in designing the study. TN participated in drafting the manuscript. All the authors approved the final version of the manuscript.

\section{Conflict of Interest}

The authors declare no conflict of interest.

\section{References}

1. Davin-Regli, A., Pagès, J. M.: Enterobacter aerogenes and Enterobacter cloacae; versatile bacterial pathogens confronting antibiotic treatment. Front Microbiol 6, 392 (2015).

2. Gad, G. F., Mohamed, H. A., Ashour, H. M.: Aminoglycoside resistance rates, phenotypes, and mechanisms of Gram-negative bacteria from infected patients in upper Egypt. PLoS One 6, e17224 (2011).

3. Garneau-Tsodikova, S., Labby, K. J.: Mechanisms of resistance to aminoglycoside antibiotics: Overview and perspectives. Medchemcomm 7, 11-27 (2016).

4. Lioy, V. S., Goussard, S., Guerineau, V., Yoon, E. J., Courvalin, P., Galimand, M., Grillot-Courvalin, C.: Aminoglycoside resistance 16S rRNA methyltransferases block endogenous methylation, affect translation efficiency and fitness of the host. RNA 20, 382-391 (2014).

5. Doi, Y., Arakawa, Y.: 16S ribosomal RNA methylation: Emerging resistance mechanism against aminoglycosides. Clin Infect Dis 45, 88-94 (2007).

6. Tada, T., Miyoshi-Akiyama, T., Kato, Y., Ohmagari, N., Takeshita, N., Hung, N. V., Phuong, D. M., Thu, T. A., Binh, N. G., Anh, N. Q., Nga, T. T., Truong, P. H., Xuan, P. T., Thule, T. A., Son, N. T., Kirikae, T.: Emergence of $16 \mathrm{~S}$ rRNA methylase-producing Acinetobacter baumannii and Pseudomonas aeruginosa isolates in hospitals in Vietnam. BMC Infect Dis 13, 251 (2013).

7. Rahman, M., Prasad, K.N., Pathak, A., Pati, B.K., Singh, A., Ovejero, C.M., Ahmad, S., Gonzalez-Zorn, B.: RmtC and RmtF 16S rRNA methyltransferase in NDM-1-producing Pseudomonas aeruginosa. Emerg Infect Dis 21, 2059-2062 (2015).

8. O’Hara, J. A., McGann, P., Snesrud, E. C., Clifford, R. J., Waterman, P. E., Lesho, E. P., Doi, Y.: Novel 16S rRNA methyltransferase RmtH produced by Klebsiella pneumoniae associated with war-related trauma. Antimicrob Agents Chemother 57, 2413-2416 (2013).

9. Bogaerts, P., Galimand, M., Bauraing, C., Deplano, A., Vanhoof, R., De Mendonca, R., Rodriguez-Villalobos, H., Struelens, M., Glupczynski, Y.: Emergence of ArmA and RmtB aminoglycoside resistance 16S rRNA methylases in Belgium. J Antimicrob Chemother 59, 459-464 (2007).

10. Yamane, K, Wachino, J., Suzuki, S., Shibata, N., Kato, H., Shibayama, K., Kimura, K., Kai, K., Ishikawa, S., Ozawa, Y., Konda, T., Arakawa, Y.: 16S rRNA methylaseproducing, Gram-negative pathogens, Japan. Emerg Infect Dis 13, 642-646 (2007). 
11. Wu, Q, Zhang, Y., Han, L., Sun, J., Ni, Y.: Plasmid-mediated 16S rRNA methylases in aminoglycoside-resistant Enterobacteriaceae isolates in Shanghai, China. Antimicrob Agents Chemother 53, 271-272 (2009).

12. Al Sheikh, Y. A., Marie, M. A., John, J., Krishnappa, L. G., Dabwab, K. H.: Prevalence of 16S rRNA methylase genes among $\beta$-lactamase-producing Enterobacteriaceae clinical isolates in Saudi Arabia. Libyan J Med 9, 24432 (2014).

13. Taylor, E., Sriskandan, S., Woodford, N., Hopkins, K. L.: High prevalence of $16 \mathrm{~S}$ rRNA methyltransferases among carbapenemase-producing Enterobacteriaceae in the UK and Ireland. Int J Antimicrob Agents 52, 278-282 (2018).

14. Sanders, W. E., Jr., Sanders, C. C.: Enterobacter spp.: Pathogens poised to flourish at the turn of the century. Clin Microbiol Rev 10, 220-241 (1997).

15. Clinical and Laboratory Standards Institute [CLSI]: Performance Standards for Antimicrobial Susceptibility Testing; Twenty-Fourth Information Supplement. Clinical and Laboratory Standards Institute, Wayne, PA, 2014.

16. Li, P., Niu, W., Li, H., Lei, H., Liu, W., Zhao, X., Guo, L., Zou, D., Yuan, X., Liu, H., Yuan, J., Bai, C.: Rapid detection of Acinetobacter baumannii and molecular epidemiology of carbapenem-resistant $A$. baumannii in two comprehensive hospitals of Beijing, China. Front Microbiol 6, 997 (2015).

17. Mir, A. R., Bashir, Y., Dar, F. A., Sekhar, M.: Identification of genes coding aminoglycoside modifying enzymes in E. coli of UTI patients in India. Sci World J 2016, 1875865 (2016).

18. Yu, F. Y., Yao, D., Pan, J. Y., Chen, C., Qin, Z. Q., Parsons, C., Yang, L. H., Li, Q. Q., Zhang, X. Q., Qu, D., Wang, L. X.: High prevalence of plasmid-mediated 16S rRNA methylase gene $r m t B$ among Escherichia coli clinical isolates from a Chinese teaching hospital. BMC Infect Dis 10, 184 (2010).

19. Yan, J. J., Wu, J. J., Ko, W. C., Tsai, S. H., Chuang, C. L., Wu, H. M., Lu, Y. J., Li, J. D.: Plasmid-mediated 16S rRNA methylases conferring high-level aminoglycoside resistance in Escherichia coli and Klebsiella pneumoniae isolates from two Taiwanese hospitals. J Antimicrob Chemother 54, 1007-1012 (2004).

20. Piekarska, K., Zacharczuk, K., Wołkowicz, T., Rzeczkowska, M., Bareja, E., Olak, M., Gierczyński, R.: Distribution of 16S rRNA methylases among different species of aminoglycoside-resistant Enterobacteriaceae in a tertiary care hospital in Poland. Adv Clin Exp Med 25, 539-544 (2016).

21. McGann, P., Chahine, S., Okafor, D., Ong, A.C., Maybank, R., Kwak, Y.I., Wilson, K., Zapor, M., Lesho, E., Hinkle, M.: Detecting 16S rRNA methyltransferases in Enterobacteriaceae by use of Arbekacin. J Clin Microbiol 54, 208-211 (2016).

22. Wangkheimayum, J., Paul, D., Dhar, D., Nepram, R., Chetri, S., Bhowmik, D., Chakravarty, A., Bhattacharjee, A.: Occurrence of acquired 16S rRNA methyltransferasemediated aminoglycoside resistance in clinical isolates of Enterobacteriaceae within a tertiary referral hospital of Northeast India. Antimicrob Agents Chemother 61, e01037-16 (2017).

23. Zhou, Y., Yu, H., Guo, Q., Xu, X., Ye, X., Wu, S., Guo, Y., Wang, M.: Distribution of 16S rRNA methylases among different species of Gram-negative bacilli with highlevel resistance to aminoglycosides. Eur J Clin Microbiol Infect Dis 29, 1349-1353 (2010). 
24. Wang, Y., Shen, M., Yang, J., Dai, M., Chang, Y., Zhang, C., Luan, G., Ling, B., Jia, X.: Prevalence of carbapenemases among high-level aminoglycoside-resistant Acinetobacter baumannii isolates in a university hospital in China. Exp Ther Med 12, 3642-3652 (2016).

25. Wachino, J., Arakawa, Y.: Exogenously acquired 16S rRNA methyltransferases found in aminoglycoside-resistant pathogenic Gram-negative bacteria: An update. Drug Resist Update 15, 133-148 (2012). 